James E. Campbell*

\title{
Explaining Electoral Change in the 2018 US Midterm Elections: The Three Components of Electoral Mandates
}

https://doi.org/10.1515/for-2018-0034

\begin{abstract}
Why did the American electorate elect a solid majority of Republicans to the House in 2016 and then 2 years later replace it with a solid majority of Democrats? This article revives the idea of an electoral mandate and applies it to the 2016 and 2018 elections. It proposes a trinity of partisan attitudes serving as the components of electoral mandates: performance, values, and leadership. The election of President Trump in 2016 depended on a mix of performance evaluations (a weak economy) favoring the Republicans and leadership evaluations (Trump's behavior difficulties) muted by value considerations (conservative anger at being unrepresented and the necessity of a choice between Trump and Clinton). These offsetting partisan attitudes made the election close enough that a small number of votes in key states decided the electoral vote outcome. In 2018, performance evaluations again favored Republicans, but now because they presided over a stronger economy. Evaluations of Trump's leadership remained negative. The interaction of values with these leadership assessments now favored Democrats. As the out-party, polarized liberals were motivated by anti-Trump anger. Never-Trump conservatives who had drifted back to vote Republican at the end of the 2016 campaign did not feel that same pressure without the presidency being at stake. About two-thirds of voters in 2018 said their vote was about Trump. Republicans lost to Democrats among these voters by 16 percentage points. Republicans delivered on their 2016 mandate to boost the economy, but had failed to provide leadership that many Americans could feel comfortable with.
\end{abstract}

*Corresponding author: James E. Campbell, University at Buffalo, SUNY, Buffalo, NY, USA, e-mail: jcampbel@buffalo.edu 


\section{Introduction}

The widely anticipated blue wave hit the shore of American politics on Election Day 2018. ${ }^{1}$ The Republican House majority was swept out to sea and a Democratic majority was left in its place. Democrats gained 41 House seats. This moved them from 194 seats following the 2016 election to 235 seats after the midterm. The 24 seat Republican majority after 2016 was replaced with an 18 seat Democratic majority. On the Senate side, Republicans added two members. This brought their numbers up to 53 , a three seat majority.

\section{An Intense Midterm Referendum}

In several respects, the 2018 midterm election was unusual. As midterms go, turnout soared. According to the US Election Project, about 50.3\% of the voting eligible population voted (McDonald 2018a). This exceeded turnout in the 2014 midterm by more than 13 percentage points. The last midterm election with turnout over $50 \%$ was held over 100 years ago (McDonald 2018b). Not coincidentally, campaign spending also soared. The Center for Responsive Politics (2018), as of late November,

\footnotetext{
1 There has been controversy over the designation of an election as a "wave" election owing to different definitions of what that entails and a lack of specificity in defining it. As I have used it, it refers to an election whose prevailing and discernable short-term forces quite consistently favor one party across the nation. In 2018, seat changes in the House lopsidedly favored the Democrats. With some adjustments to take into account the court-drawn redistricting between elections in Pennsylvania, 43 seats flipped from Republicans to Democrats and only two (Minnesota 1 and Pennsylvania 14) went the other way. At first glance, with Republicans picking up two seats (precisely as predicted by my seats-in-trouble model (Campbell 2018)), conditions in Senate elections might appear to have been running in favor of Republicans. This, however, is an illusion created by Democrats having many more seats to defend in this cycle ( 26 of the 35 up for election). The climate (to mix metaphors) of past elections for this class of Senators had favored Democrats, particularly in 2000 and 2006. So a fairly strong Democratic climate in 2016 was necessary to hold their pre-election numbers. Because of the greater attention individual Senate races receive, they are also less influenced by and reflective of national political conditions than House races. Finally, the Republican gain of two Senate seats should be seen in the context of Democrats winning 24 of the 35 Senate seats up in 2018 (69\%). Even with many of the seats up in 2018 being in safely Democratic states (e.g. California, Rhode Island, New York, Connecticut, Vermont, Massachusetts), 20 of the 35 Senate races were held in states carried by President Trump in 2016. Republicans in 2018 only won 11 of the 20 Senate races in states Trump carried in 2016. Even with the loss of a couple of Senate seats, the political climate favoring Democrats in 2018 was evident.
} 
projected that $\$ 5.2$ billion was spent by candidates, the parties, and PACs. By these incomplete numbers, campaign spending in 2018 increased by 35\% over 2014. The greater intensity behind both the turnout and spending increases reflects the high level of polarization in the public and between the parties as well as the unusually strong feelings about President Trump (Campbell 2016).

Although unusual in its intensity, the 2018 midterm ran true to form in other respects. As usual in midterms, the president's party lost House seats (Campbell 1997). The presidential party sustained seat losses in the House in all but three of the 38 midterms since $1870 .^{2}$ The three exceptions were cases in which presidents were unusually popular at the time of the midterm (FDR in 1934, Clinton in 1998, and G.W. Bush in 2002). ${ }^{3}$

Although the fact of midterm seat losses for the president's party has been nearly a constant, the extent of these losses has varied quite a bit. The size of midterm seat losses depends, in no small part, on how popular the president is during the midterm campaign (Tufte 1975; Lewis-Beck and Rice 1984; Campbell 1997). Table 1 presents a simple sort of midterm election outcomes in 15 midterms since $1954 .{ }^{4}$ Midterms are sorted into two groups-those in which the president was relatively popular and those in which the president was less popular. More popular presidents are defined as those with Gallup job approval ratings in early September (or as near to then as was available) greater that 53\%. Less popular presidents are defined as having Gallup approval ratings under 47\% (Gallup 2018). ${ }^{5}$

The importance of presidential approval is clearly evident in this simple division. When presidents were popular, their party's seat losses were minimal, typically in single digits. On the other hand, the president's party normally took

2 The in-party also gained seats in the 1902 midterm election, but only because the size of the House of Representatives increased between the 1900 and 1902 elections. The in-party's percentage of seats in 1902 declined.

3 These approval numbers are drawn from Gallup (2018) and the Roper Center (2018). Riding a crest of economic prosperity from two economic bubbles, the "dot com" internet bubble and the real estate bubble, President Bill Clinton had approval ratings in the mid-1960s range and his party gained 5 seats in the 1998 midterm. In the months following the 9/11 terrorist attacks, President George W. Bush's approval ratings were also in the mid-1960s range and his party gained 8 seats in 2002. Although approval polls were not frequently conducted in President Franklin Roosevelt's early terms, he was elected in 1932 in a landslide and reelected in 1936 in a landslide, so it is probably safe to conclude that he was quite popular in 1934 when his party gained 9 seats in the midterm.

4 A sixteenth midterm, 1974, was excluded because of its unusual circumstance. President Ford had only recently ascended to the presidency after President Nixon's resignation.

5 The analysis was also conducted using late October approval ratings. These later ratings generated the identical division of midterms for more and less popular presidents (Gallup 2018). 
Table 1: Midterm Seat Losses in the US House of Representatives by Presidential Approval Ratings, 1954-2018.

\begin{tabular}{|c|c|c|c|c|c|c|c|}
\hline \multicolumn{4}{|c|}{$\begin{array}{l}\text { More Popular Presidents at the Midterm } \\
\text { (Approval>53\%) }\end{array}$} & \multicolumn{4}{|c|}{$\begin{array}{l}\text { Less Popular Presidents at the Midterm } \\
\text { (Approval }<47 \% \text { ) }\end{array}$} \\
\hline President & Midterm & Approval & Seat Loss & President & Midterm & Approval & Seat Loss \\
\hline G.H.W. Bush & 1990 & 74 & -8 & Johnson & 1966 & 46 & -48 \\
\hline Kennedy & 1962 & 67 & -4 & Obama & 2010 & 45 & -64 \\
\hline G.W. Bush & 2002 & 66 & +8 & Reagan & 1982 & 42 & -25 \\
\hline Eisenhower & 1954 & 63 & -18 & Carter & 1978 & 42 & -15 \\
\hline Clinton & 1998 & 63 & +5 & Trump & 2018 & 40 & -41 \\
\hline Reagan & 1986 & 61 & -5 & Obama & 2014 & 40 & -13 \\
\hline Eisenhower & 1958 & 57 & -48 & G.W. Bush & 2006 & 39 & -30 \\
\hline Nixon & 1970 & 55 & -12 & & & & \\
\hline Mean & & 63.3 & -10.3 & & & 41.6 & -36.3 \\
\hline Median & & 63 & -6.5 & & & 41 & -35.5 \\
\hline
\end{tabular}

Approval ratings are of early September from Gallup (2018). The means and medians were the same in using late October approval ratings. No president in this period had approval ratings between $47 \%$ and $53 \% .1974$ is excluded since President Ford had only been in office for a short while before the midterm campaign that year.

a beating when the midterm electorate was less pleased with the president. The median seat loss for the party of less popular presidents was 35 seats. There is, of course, variation within each of these two groups, likely owing to what happened in the previous presidential election, but the overall midterm referendum on the president's job performance shows through quite clearly nonetheless.

The 2018 midterm election was a normal election from this perspective. President Trump's approval rating in early September of 2018 (and late October) was $40 \%$ according to Gallup (2018) and was $45 \%$ in the exit polls. ${ }^{6}$ As a relatively less popular president, like his predecessor President Obama, big midterm losses in the House were to be expected. From a different perspective, my "seatsin-trouble" forecasting model of House seat change (essentially forecasting the outcome of a normal election under the circumstances) predicted in mid-August that Democrats would gain 44 seats over their 2016 numbers, only three seats off of election's outcome (Campbell 2018). ${ }^{7}$

6 References to the 2016 and 2018 exit polls are to the national exit polls reported in those years on the CNN website (CNN 2016a, 2018).

7 Republican seat losses, for the most part, were where one would expect them to be. In districts carried by Hillary Clinton in 2016 (21 districts) and in districts rated by the Cook Political Report's Partisan Voting Index (PVI) as leaning to the Democrats or competitive in their partisanship (34 districts) (Cook Political Report 2018). 
Based on this, we could conclude that the Republican Party in the 2018 midterm elections lost 41 seats because the public's approval of the job performance of President Trump was more negative than positive. That conclusion, however, only begs the question. Why was President Trump's approval rating at the midterm as low as it was? Why did the American electorate elect a solid majority of Republicans to the House of Representatives in 2016 then 2 years later replace it with a solid majority of Democrats? What explains the 2016 election and the electoral turn around in 2018? What changed?

\section{Interpreting Electoral Mandates}

These questions raise a larger question of how elections can be generally explained - why did an electorate elect one candidate rather than another? Why did the winner win and the loser lose? What decided the election? No area of American politics has been more thoroughly studied than voting behavior, yet our understanding and interpretation of election results has not received the serious attention it deserves. The determination of why voters decided to vest powers with one leader rather than another is at the core of democratic representation in governing and is critical to future elections (Stokes, Campbell, and Miller 1958, 1966; Kelley 1983; Jones 1991). Leaders or parties who ignore or misconstrue an electorate's mandate do so at their own political peril both during their tenure and at their next election. They may well have good reasons occasionally not to heed an electorate's wishes, but they ought to know they are doing so and what risks they are taking with their political futures.

As important as it is, the idea that elections provide mandates by the electorate to those elected has met with a great deal of resistence by scholars (Kelley 1983, p. 129-137; Dahl 1990; Hershey 1994). A major reason for skepticism about mandates is that they are difficult, some might say impossible, to determine what they are with certainty. Elections can involve hundreds of millions of voters, each one having many different ideas about why they are voting for or against a particular candidate. A vote is a blunt instrument. Out of all of this, when so many voters were saying so many things, how can anyone reliably say that what the collective message was or that there was anything close to a coherent collective message that leaders could discern?

Indeed, errors are easily and often made in interpreting elections. For example, one notable interpretation of the 2016 election erroneously dismissed the possibility that anger in the electorate played a major role in deciding the election's outcome (Sides, Tesler, and Vavreck 2017, p. 35). The authors incorrectly 
reasoned that voter anger did not make a difference because, as they put it, "there was no increase in 'anger' among Americans heading into 2016.” Of course, anger does not need to increase for it to remain a potent motivation. Change in anger levels is irrelevant. What is relevant to affecting and interpreting an election is the level of anger and what that anger is about. As many of the skeptics of mandates contend and as this example illustrates, interpreting elections is difficult. That interpreting elections is difficult, however, does not mean their interpretation is any less important.

Some have gone further to claim that mandates do not exist, that "election outcomes have little real policy content (Achen and Bartels 2016, p. 319).” This view asserts that citizens are too ignorant, misinformed, and politically uninterested for election outcomes to have any substantive meaning. Lacking minimal civic competence in the public a representative democracy and substantively meaningful elections amount to merely a romantic myth. Mandates can not be accurately deciphered, according to this view because voters do not imbue elections with any substantive meaning.

These extreme claims, however, fall far short of being credible. ${ }^{8}$ The deficiencies of citizens have long been well documented. Undoubtedly, many come up well short of what might be expected. However, while some votes are cast for frivolous reasons, most are not. Voters are certainly imperfect, but most do not act randomly or in lock step with those with whom they share some socio-demographic characteristic. They have opinions and preferences - many of which we are able to measure fairly well on surveys. ${ }^{9}$ As an abundance of voting behavior research

8 In addition to the lengthy list of studies over the decades finding evidence of substantive voter decision-making, there are many problems in the research used to support Achen and Bartels' claim of what might be termed "clueless voting." For instance, in examining changes between the 1912 and 1916 presidential elections in New Jersey, they find that President Wilson fared worse in the coastal counties in 1916. The reason for this was attributed to his being nonsensically blamed for a series of shark attacks. An alternative explanation in which voters are not characterized as witless fools is that Republicans who voted for Bull Moose candidate Teddy Roosevelt, who had bolted from the Republican Party in 1912, came home their party to vote for Republican Charles Evans Hughes in 1916. Roosevelt had run particularly strongly in the coastal (shark attack) counties in 1912 and Wilson's percentage of the 2016 vote would have thereby suffered in these counties as Roosevelt's 1912 voters voted for Hughes in 1916 (Achen and Bartels 2016, p. 124 n.12).

9 Some opinions are undoubtedly affected by motivated reasoning, rationalization. Even so, it takes some concern about inconsistency for voters to bother to rationalize and some awareness of it to be able to rationalize. There must also be some pre-existing preference which serves as a motivator to rationalize. In short, in some respects the rationalization of opinions may indirectly speak well of the voters' cognitive capacities and awareness of inconsistencies. 
has well established, a great many votes are grounded in substantive reasons and some of these affect how elections are decided (Campbell et al. 1960; Key 1966; Kelley 1983; Lewis-Beck et al. 2008)

The most important and understandable reason for skepticism about electoral mandates is how they have been commonly defined. Though there is no settled definition, as frequently used, mandates require declarations from the public that are unrealistically strong, clear and specific and the standards determining the strength, clarity, and specificity requirements are frustratingly indefinite. In some cases, mandates are accepted as the claims of what elites declare them to be rather than as what moved the critical number of voters to decide the election's outcome (Conley 2001; Grossback, Peterson, and Stimson 2007; Azari 2013). A more useful, focused, and realistic definition of an electoral mandate is the reason or reasons why the electorate decided as it did. By this definition, mandates are drawn from the electorate, not from what elected leaders or anyone else declares about the electorate's motives. The voice of the people can be as strong or weak and as specific or general as they want it to be.

\section{The Components of Mandates}

Even with this clearer and more realistic but also more expansive definition of mandates, deciphering what the election's result "turned on" is exceedingly difficult. Many modern efforts at interpreting elections are somewhat ad hoc and not well structured by prior voting research.

This is not far from where we stood 60 years ago when three of the four members of The American Voter team of election pioneers wrote in their article on "Components of Electoral Decision” (Stokes, Campbell, and Miller 1958) about the question "What combination of forces elects a President?" and the chaotic array of answers to it when applied to the 1956 presidential election. They proposed a framework to their analysis of what elections mean. That structure consisted of six broad partisan attitudes that organized what voters considered in making up their minds about their individual vote choices and what in the aggregate they were conveying to the leaders they elected (Campbell et al. 1960; Stokes 1966).

The six partisan attitudes, examined to understand the most proximate thinking about the vote choice and election outcomes (near the tip of The American Voter's "funnel of causality" rather than more remote circumstances and predispositions), spanned the range of substantive concerns. These were drawn from responses to a battery of general open-ended questions asking respondents about what they liked and disliked about the parties and candidates. The six 
partisan attitudes composing this classification of responses included attitudes related to: (1) the Democratic candidate as a person; (2) the Republican candidate as a person; (3) group-related associations; (4) domestic policy; (5) foreign policy; and (6) the general performance of the parties and candidates in managing the nation's affairs. ${ }^{10}$

The six partisan attitudes affecting the vote and ultimately election outcomes are comprehensive, but not drawn from an organizing principle. The categorization, as a result, has a somewhat ad hoc quality to it. A natural organizing principle for making sense out of the many considerations of voters can be found by going back to the first principles of campaigning: the primacy of "the message" (as in James Carville's admonition in 1992 that "it's the economy, stupid”). In broad terms, the message of a campaign amounts to the reasons forwarded by the candidates or anyone else for why a prospective voter should vote for one candidate rather than another. These proposed reasons fall into three categories: past performance (the record, outcomes, retrospective evaluations), values (promises, policy, prospective outlooks), and leadership (the messenger). Strictly speaking about the message, prospective voters are asked to vote for or against a candidate or party because of what they had done in the past (as Ronald Reagan asked voters pointedly in 1980, “are you better off today than you were 4 years ago?”) or because of what they propose or are likely to do in the future. But voting for a candidate also involves a leap of trust in the honesty and competence of those asking to be elected. The elements of leadership are also important components of the vote. The messenger as well as the message is part of the package voters are asked to decide upon.

So how did the trinity of the electorate's fundamental partisan attitudes-performance, values and leadership-lead to the outcome of the 2018 midterm?

\section{Three Partisan Attitudes in 2016}

The electoral verdict of 2018 cannot be understood without first understanding why the electorate decided 2016 as it did. Why did voters elect Donald Trump to the presidency in 2016 and with him 241 Republicans to the House? To clarify, this

10 An earlier categorization in The Voter Decides consisted of three components: party identification, issue orientations, and candidate orientations (Campbell, Gurin, and Miller 1954). Downs (1957) also identified past performance (41-5), values (96-103) and leadership (87-8, 107-9) as crucial considerations in his analysis of voting. Fiorina (1981) also seems to be consistent with a retrospective (performance) and prospective (values) and leadership structure. Stokes (1985) also wrote about the performance component as valence issues and the values component as position issues. 
is not to ask why fewer than eighty thousand voters in a three states (Pennsylvania, Michigan, Wisconsin) tipped the electoral vote majority to Donald Trump. It is instead to ask why the election was close enough that so few votes were able to decide it. Hillary Clinton was a candidate with extensive political experience and faced an opponent with none. She and her supporters outspent her opponent and his supporters by two to one (Center for Responsive Politics 2018). Although she received plenty of bad press, it was much less unfavorable than her opponent's press (Patterson 2017). Clinton faced a stiff challenge from Sanders for her nomination, but Democrats were far more unified around her than Republicans were around Trump. Yet despite all of these important advantages, she was only barely able to win a plurality of the popular vote and lost the electoral vote to an opponent who was widely thought to be unelectable, who frequently engaged publicly in embarrassing gratuitous feuding, and who had earned the public disdain of most of his party's establishment. Why did this happen?

There is no shortage of explanations for what happened in 2016. Without taking these on one at a time, a task requiring many more pages than available here, we can safely set aside or dismiss outright the ideas that the outcome hinged on Russian hacking of the emails of prominent Democrats, FBI Director Comey's late in the campaign reopening of the investigation into Clinton's mishandling of classified emails, voter suppression, an increase in racial resentment, or any number of other theories.

The outcome of the 2016 election involved each of the three fundamental partisan attitudes. First, the performance of the in-party favored the Republicans. The electorate was not pleased with the record of the Obama administration. ${ }^{11}$ In the 2016 exit polls, 62\% said the economy was "not good" or "poor."12

11 Sides, Tesler, and Vavreck (2017) incorrectly claim the economy in 2016 actually favored the in-party Democrats. This ignores the evidence in the exit polls and in other polling of widespread public dissatisfaction with the economy. It also ignores the historical association of election year GDP growth, opinions about the economy, and the in-party vote. Their mistaken interpretation is based on two errors in their analysis. First, they conduct a regression of GDP growth against the in-party vote share and observe that the 2016 case is as expected, a Democratic plurality. The problem with this is that their analysis does not correct or adjust for the attenuating effect of the considerable diminishing negative returns of the 1980 case. Once this is corrected for, Democrats fared much better than they would have if only economic conditions mattered. Second, they report that conditions in 2016 were better than they were in 2012 (true) and President Obama was reelected under those conditions in 2012. What their analysis fails to take into account is that most (77\% in the exit polls) of the 2012 electorate said they thought the economy was "not so good" or "poor," but most did not blame President Obama for this. They blamed former President George W. Bush (53\% Bush vs. 38\% Obama in the exit polls).

12 In the same exit poll, $62 \%$ of voters also said the nation was on "the wrong track." Although this is likely good news for the out-party, there is ambiguity in the response. For some respondents it may mean that the in-party Democratic liberals had not gone far enough to the left. 
A regression of real GDP growth in the quarters during the Obama presidency after the "Great Recession" ended indicated no trend of improvement. Real GDP growth had flat-lined at just over $2 \%$ growth, about a full percentage point below the median growth rate in the post-WWII period (33\% below average). In the four quarters of 2016, real GDP growth exceeded two percentage points on only the second quarter and then fell short of 2.5\% growth (Bureau of Economic Analysis 2018). Most tellingly, the economy was thought to be so fragile in 2016 that the Federal Reserve Board's monetary policy maintained its low pro-stimulus "discount and advance rates" begun during the economic collapse of $2008 .^{13}$ The Fed did not regard the economy as stable enough to risk the easing back to higher interest rates. The electorate concurred. Advantage Republicans.

The second partisan attitude in play in 2016 was leadership. Throughout the election year, poll after poll reported a majority of respondents holding unfavorable opinions of both Clinton and Trump, but with more prospective voters holding Trump in low esteem. In Gallup's daily tracking polls in mid October, Trump's unfavorables averaged about ten points higher than Clinton's (about 65\% to 55\%). The exit polls asked about the candidates' leadership traits-honesty and trustworthiness, temperament, and whether they were qualified to be president. Clinton fared better than Trump with voters on each of the leadership qualities (though just barely on honesty and trustworthiness). Advantage Democrats.

The values of the electorate, reflected in their ideological polarization, was the third partisan attitude affecting the 2016 outcome. In their direct effect on the election, values slightly favored Republicans-tilting by two percentage points toward a more conservative president than the incumbent and by five points toward a less active government. But it was the interaction of values and political circumstances that was most important.

Being out of power when politics are so polarized is particularly frustrating and the anger on the right had been building up for some time. From President George H.W. Bush reneging of his "read my lips, no new taxes" pledge, to the big spending "compassionate conservatism" of George W. Bush, to the maverick conservatism of John McCain and the self-described "severely conservative" Mitt Romney, conservatives felt unrepresented in the system. Even when they won big, as they had in the 2010 midterm, they had little in the way of policy to show for it.

13 The anemic state of the 2016 economy was also evident in other data. Nearly 10 million more Americans in 2016 still received supplemental nutrition assistance (food stamps) than when President Obama took office in 2009 (USDA 2018). Also, though unemployment rates had declined a bit, so had labor force participation (Bureau of Labor Statistics 2018). 
Their anger came through most clearly in a Pew Research Center study conducted in late 2015. It asked whether "on issues that matter to you in politics today, has your side been winning or losing more often?” Only 44\% of liberal Democrats thought they were usually on the losing side. In sharp contrast, $81 \%$ of conservative Republicans said they usually got the short end of the stick (Pew Research Center 2015, p. 10). Many conservatives felt unrepresented by the system and by their own party. In the exit polls during the primaries, about $41 \%$ of Republican voters on average said they were "angry" about the federal government and another 49\% said they were "dissatisfied." In those same primary exit polls, about $54 \%$ of Republican primary voters reported feeling "betrayed" by Republican politicians (CNN 2016b).

By 2016, conservatives were livid. Being on the outs in a highly polarized environment made them determined to prevent another 4 years of a liberal in the White House, but many faced a tough choice. According to Gallup (2016), better than a third of Republicans in mid-October held unfavorable views of their own party's candidate..$^{14}$ They thought Donald Trump was unfit for office. ${ }^{15}$ Despite Clinton being unacceptable to them ideologically and having her own perceived liabilities in leadership, a significant number of conservatives were in sympathy or were part of the "Never Trump" movement. ${ }^{16}$

But as Election Day approached, an unpleasant choice forced by the anger and the ideology of many "Never Trump" conservatives was clear. It was not a vote they felt comfortable about, but the alternative was worse. They were sick and tired of losing. They wanted desperately to win. If nothing else, Trump was all about winning.

Many would rationalize their views of Trump as they reluctantly came to the decision to vote for him. According to Gallup (2016), Trump's unfavorables among Republicans declined by about 6 or 7 points from mid-October to Election Day (34-35\% to 28\%). This accounts for much of the overall 5 point decline in

14 The internal party divisions had been deepening throughout the nomination season. In a survey conducted in June before the conventions, $72 \%$ of Democrats said they thought their party would unite solidly behind Clinton while only $38 \%$ of Republicans predicted the same party unity for Trump (Pew Research Center 2016, p. 8).

15 Opinion in GOP establishment ranks was so vehemently against Trump that in its August 13, 2015 edition, the highly regarded “Sabato's Crystal Ball” website created a special category in handicapping Trump's chances at capturing the GOP nomination: "The Un-Nominatable Frontrunner" (Sabato, Kondik, and Skelley 2015).

16 The 2016 exit polls indicate that $61 \%$ of voters thought Clinton was not honest or trustworthy and $44 \%$ thought she lacked the temperament to be president. 
unfavorables in the broader electorate (65\% to 60\%), and the two point increase in Trump's share of the national two-party vote preferences in the last 2 weeks of the campaign. ${ }^{17}$ Several polls conducted during the campaign found Republicans to be three to eight percentage points less loyal in their vote intentions than Democrats. By the time of the election, this gap had been eliminated.

In the end, a fifth (based on the exit polls) to as much as a third (based on mid-October polls (Gallup 2016)) of Trump's total vote came from voters who held unfavorable views of him. Of those simultaneously holding unfavorable views of both Clinton and Trump (about 18\% of voters), Trump beat Clinton by 18 points (47\% to $30 \%){ }^{18}$

The bottom line of the 2016 election is that evaluations of performance (primarily the economy) favored the Republicans, but evaluations of leadership favored the Democrats (the perceived deficiencies of Trump as a potential president). The later were muted by considerations of values (some conservatives would set aside their disdain for Trump to avoid Clinton). In a word: polarization. This left the election closely enough decided that a relatively small number of votes in the industrial midwest could swing an electoral vote majority to Donald Trump.

\section{From 2016 to 2018 ?}

So what changed or perhaps did not change between 2018 and 2016 that would account for the reversal of fortunes in the House?

The partisan attitude of the parties' performance on the key element of the economy was pretty much unchanged between the elections. The economy

17 It should be observed that the decline in Trump's unfavorables among Republicans and overall in the closing weeks of the campaign, while Clinton's unfavorables remained quite constant (both overall (55\%) and among Democrats (21\%)), undercuts claims that the erosion of Clinton's lead in preference polls in the last weeks of the election was due in any way to FBI Director Comey's late reopening of investigation into Clinton's mishandling of emails or to the late posting by Wikileaks of Russian hacked Democratic emails. If these factors had made a difference, we should have expected an increase in Clinton's unfavorables. That increase did not occur. Moreover, neither the Comey development nor the Wikileaks development would explain the decline in Trump's unfavorables.

18 When asked in the exit polls whether they strongly favored the candidate they voted for, had reservations about that candidate, or voted for the candidate because they disliked the opponent, $28 \%$ of Trump voters reported they voted for him because they disliked Clinton. Another $34 \%$ of Trump voters had "reservations" about him. 
Table 2: The Electorate's Perceptions of Economic Performance, 2016 and 2018.

\begin{tabular}{lll}
\hline Perceptions of the Economy & \multicolumn{2}{l}{ \% Opinion of Respondents } \\
\cline { 2 - 3 } & $\mathbf{2 0 1 6}$ & $\mathbf{2 0 1 8}$ \\
\hline Excellent or Good & 36 & 68 \\
Not So Good or Poor & 62 & 31 \\
Difference & -26 & +37 \\
Party Favored by Evaluations of the Economy & The Out-Party, & The In-Party, \\
& The Republicans & The Republicans \\
\hline
\end{tabular}

Source: CNN 2016 and 2018 Exit Polls.

changed, it improved a good bit, but because of the change in presidential party (from the Democrat Obama to the Republican Trump) the partisan consequences did not change. In 2016 real GDP in the first three quarters the election year grew at weakly positive rates: 1.5\% Q1, 2.3\% Q2, and 1.9\% in Q3 (Bureau of Economic Analysis 2018). The median growth rate in quarters since these data first became available in 1947 has been 3.1\%. As presented in Table 2, this sub-par performance was accurately perceived by voters, with $62 \%$ in the exit polls reporting negative opinions about economic conditions. This favored change to the out-party Republicans.

By 2018, the economy had improved. Although the year got off to a ho-hum start, it picked up in later quarters: 2.2\% Q1, 4.2\% Q2, and 3.5\% in Q3. Voters noted the improvement. In the 2018 exit polls, 68\% reported positive impressions of the economy. An electorate pleased about the state of the economy was good news for the now in-party Republicans. As such, and with no other burning performance consideration in 2018, performance considerations do not help to explain why President Trump's approval rating was low and why Republicans lost so many House seats.

The explanation of the blue wave in 2018 is found in the electorate's evaluation of leadership. A substantial majority of the 2016 electorate, as already noted, did not think highly of Donald Trump's leadership potential. Large majorities thought he was not honest or trustworthy (64\%), not qualified (61\%), and lacked the proper temperament to be president (63\%). A large majority held overall unfavorable views of him (60\% in the exit polls). Many holding these less than flattering views of Trump were conservatives and moderates and many of them ended up voting for Trump anyway because they faced a choice of either Trump or Clinton and saw Trump as the "lesser of two evils" and of a polarization-fueled anger of being too often on the losing political side.

Opinions of President Trump's leadership had not changed much by 2018. An average of ten polls conducted between April and October of 2018 indicated 
$57 \%$ of Americans held an unfavorable view of President Trump (Polling Report. com 2018). According to The Fox News Voter Analysis (2018) around Election Day, $53 \%$ of voters held unfavorable views. As in 2016, large majorities continued to think Trump was not honest or trustworthy (62\%) and lacked the proper temperament to be president (64\%). The Fox study also found that 58\% of voters in 2018 did not believe President Trump cared about people like themselves.

These views of leadership in 2018 were basically unchanged from what they had been in 2018, but what had changed were two important contexts and they made a huge difference. First, since they do not involve the election of a president, midterm elections are more readily regarded by voters as a referendum on the in-party and its president than a choice between parties and their leaders. In a sense, some voters holding Trump in low esteem in 2016 may have felt the pressure of making a choice between him and his liberal and flawed opponent. They eventually came back to their party and its candidate. In 2018, without the presidency at stake, that pressure was relieved.

Second, the motivating anger of polarized voters who were out of power shifted from the right to the left as a result of the controversial 2016 election. In 2016, conservatives who felt disenfranchised were desperate to get back into power. Many would overlook or put up with what they believed were the many leadership shortcomings of Donald Trump if he could help them prevent the continuation of what they say as the radical misrule of the Obama years. The results of the 2016 election offered them relief, an uneasy relief given Trump's leadership style, but nonetheless a relief.

The anger of being polarized and out of power now shifted to the left for 2018. Many liberals found a Trump presidency to be an abomination. As the right saw the election of liberals as the result of voter fraud, the left now saw a Trump victory as rigged by voter suppression and Russian "meddling." Their anger showed up in the high voter turnout and campaign contribution numbers as well as in the 2018 exit poll and the Fox News Analysis Survey. Most of those holding negative opinions of President Trump - the 54\% who disapproved of his performance in office and the 53\% who held an overall unfavorable opinion of him - reported holding these views "strongly." With respect to both approval and favorability, about 44\% said their impressions were strongly negative and they voted overwhelmingly (about 90\%) for Democratic House candidates. In contrast, only about $30 \%$ of voters said they had strongly positive impressions of the president.

The 2018 midterm election turned on the partisan attitudes about leadership, again interacting with values-fueled anger on the left in this election. Table 3 displays the crucial clue to interpreting 2018. The exit polls and Fox News Analysis Surveys asked voters whether a reason for their vote had been to express either support for or opposition to President Trump? Nearly two-thirds (63\%) claimed 
Table 3: Trump as a Factor in Midterm Voting, 2018.

\begin{tabular}{lrr}
\hline Was Trump a Factor in Vote for the US House? & \multicolumn{2}{c}{ \% House Vote of Respondents } \\
\cline { 2 - 3 } & Democratic Vote & Republican Vote \\
\hline Trump was a factor (64\%) & 57 & 41 \\
Factor: To Support Trump (26\%) & 4 & 95 \\
Factor: To Oppose Trump (38\%) & 94 & 4 \\
Trump was not a factor (33\%) & 44 & 52 \\
\hline
\end{tabular}

Source: CNN 2018 Exit Polls. Fox News Analysis 2018 numbers differed only by a point or two.

their vote had been directed at President Trump and a large majority of them said their vote was cast as expression of opposition to Trump. Looking at this from another angle, if Trump was the focus of the vote, as it was for a majority of voters, congressional Republicans lost to congressional Democrats by 16 points. Among those whose vote was not about Trump (about a third of voters), congressional Republicans beat congressional Democrats by 8 points.

There had been two components to the mandate of 2016: restore greater vitality to the economy and govern in a way that Americans can feel proud of or at least feel comfortable with. Republicans appear to have delivered fairly well on the first component, but not on the second. Trump was still being Trump and, though that sells well in some corners, overall it is a political liability and was one in 2018.

\section{References}

Achen, Christopher H., and Larry M. Bartels. 2016. Democracy for Realists: Why Elections Do Not Produce Responsive Government. Princeton, NJ: Princeton University Press.

Azari, Julia R. 2013. "Institutional Change and the Presidential Mandate." Social Science History 37 (4): 483-514.

Bureau of Economic Analysis. 2018. "Table 1.1.1. Percent Change From Preceding Period in Real Gross Domestic Product.” National Data: National Income and Product Accounts. https://apps.bea.gov/iTable/iTable.cfm?reqid=19\&step=2\#reqid=19\&step=2\&isuri=1\&19 21=survey.

Bureau of Labor Statistics. 2018. “Databases, Tables \& Calculators by Subject.” https://data. bls.gov/timeseries/LNS14000000.

Campbell, James E. 1997. The Presidential Pulse of Congressional Elections. 2nd ed. Lexington, KY: The University Press of Kentucky.

Campbell, James E. 2016. Polarized: Making Sense of a Divided America. Princeton, NJ: Princeton University Press.

Campbell, James E. 2018. "The Seats-in-Trouble Forecasts of the 2018 Midterm Congressional Elections.” PS: Political Science \& Politics 51 (S1): 12-16. 
Campbell, Angus, Gerald Gurin, and Warren Miller. 1954. The Voter Decides. Evanston, IL: Row, Peterson, and Co.

Campbell, Angus, Philip E. Converse, Warren E. Miller, and Donald E. Stokes. 1960. The American Voter. New York: John Wiley and Sons.

Center for Responsive Politics. 2018. "Cost of Election." Open Secrets. Accessed December 8, 2018. https://www.opensecrets.org/overview/cost.php.

CNN. 2016a. "Exit Polls, National President." https://www.cnn.com/election/2016/results/ exit-polls.

CNN. 2016b.“Republican Exit Polls, Democratic Exit Polls.” https://www.cnn.com/election/2016/primaries/polls.

CNN. 2018. "Exit Polls." https://www.cnn.com/election/2018/exit-polls.

Conley, Patricia Heidotting. 2001. Presidential Mandates: How Elections Shape the National Agenda. Chicago: University of Chicago Press.

Cook Political Report. 2018. "Partisan Voting Index.” https://www.cookpolitical.com/pvi-0.

Dahl, Robert A. 1990. "Myth of the Presidential Mandate." Political Science Quarterly 105 (3): 355-372.

Downs, Anthony. 1957. An Economic Theory of Democracy. New York: Harper and Row.

Fiorina, Morris P. 1981. Retrospective Voting in American National Elections. New Haven, CT: Yale University Press.

Fox News. 2018. “Fox News Voter Analysis.” https://www.foxnews.com/midterms-2018/voteranalysis.

Gallup. 2016. “Presidential Election 2016: Key Indicators.” https://news.gallup.com/ poll/189299/presidential-election-2016-key-indicators.aspx.

Gallup. 2018. “Presidential Approval Center.” https://news.gallup.com/interactives/185273/ presidential-job-approval-center.aspx.

Grossback, Lawrence J., David A. M. Peterson, and James A. Stimson. 2007. "Electoral Mandates in American Politics.” British Journal of Political Science 37 (4): 711-730.

Hershey, Marjorie Randon. 1994. "The Meaning of a Mandate: Interpretations of 'Mandate' in 1984 Presidential Election Coverage.” Polity 27 (2): 225-254.

Jones, Charles 0. 1991. "Meeting Low Expectations: Strategy and Prospects of the Bush Presidency." In The Bush Presidency: First Appraisals, edited by Colin Campbell and Bert A. Rockman, 37-68. Chatham, NJ: Chatham House Publishers.

Kelley, Stanley Jr. 1983. Interpreting Elections. Princeton, NJ: Princeton University Press.

Key, Jr. V.O., and Milton C. Cummings Jr. 1966. The Responsible Electorate: Rationality in Presidential Voting, 1936-1960. New York: Vintage Books.

Lewis-Beck, Michael S., and Tom W. Rice. 1984. “Forecasting U.S. House Elections.” Legislative Studies Quarterly 9 (3): 475-486.

Lewis-Beck, Michael S., William G. Jacoby, Helmut Norpoth, and Herbert F. Weisberg. 2008. The American Voter Revisited. Ann Arbor, MI: University of Michigan Press.

McDonald, Michael. 2018a. “2018 November General Election Turnout Rates.” http://www. electproject.org/2018g.

Michael McDonald. 2018b. “U.S. VEP Turnout 1789-Present.” http://www.electproject. org/2018g.

Patterson, Thomas E. 2017. “Figure 5. Nominees' Coverage, by Week.” Reports on News Coverage of 2016 Presidential Campaign, General Election Period.” https://scholar.harvard.edu/ thomaspatterson. 
Pew Research Center. 2015. “Beyond Distrust: How Americans View Their Government.” 11/23/15. http://www.people-press.org/2015/11/23/beyond-distrust-how-americans-viewtheir-government/.

Pew Research Center. 2016. “2016 Campaign: Strong Interest, Widespread Dissatisfaction.” 7/7/16, p.4. http://www.people-press.org/2016/07/07/2016-campaign-strong-interestwidespread-dissatisfaction/.

Polling Report.Com. 2018. "Donald Trump: Favorability Ratings.” http://www.pollingreport. com/trump_fav.htm.

Roper Center. 2018. "Presidential Approval.” https://presidential.roper.center/.

Sabato, Larry J., Kyle Kondik, and Geoffrey Skelley. 2015. “Republicans 2016: What to Do with The Donald?” Sabato's Crystal Ball. August 13, 2015. http://crystalball.centerforpolitics. org/crystalball/articles/republicans-2016-what-to-do-with-the-donald/.

Sides, John, Michael Tesler, and Lynn Vavreck. 2017. “The 2016 U.S. Election: How Trump Lost and Won." Journal of Democracy 28 (2): 34-44.

Stokes, Donald E. 1966. "Some Dynamic Elements of Contests for the Presidency." American Political Science Review 60 (1): 19-28.

Stokes, Donald E. 1985. "The Paradox of Campaign Appeals and Election Mandates." Proceedings of the American Philosophical Society 129 (1): 20-25.

Stokes, Donald E., Angus Campbell, and Warren E. Miller 1958. "Components of Electoral Decision." American Political Science Review 52 (2): 367-387.

Tufte, Edward R. 1975. "Determinants of the Outcomes of Midterm Congressional Elections." American Political Science Review 69 (3): 812-826.

USDA (United States Department of Agriculture). 2018. "National Level Annual Summary: Participation and Costs, 1969-2017." Supplemental Nutrition Assistance Program (SNAP) https://fns-prod.azureedge.net/sites/default/files/pd/SNAPsummary.pdf.

James E. Campbell is a UB Distinguished Professor of Political Science at the University at Buffalo, SUNY. He is the author of four books and more than 80 research articles and book chapters on American politics. His most recent book is Polarized: Making Sense of a Divided America (Princeton, 2016). 